\title{
Study on Hydrogen Production System by Coupling with DSSCs
}

\author{
Di Gu1*, Hongwen Gu², Yanji Zhu1, Chuang Zhang3, Dianxu Zhang4 \\ ${ }^{1}$ College of Chemistry and Chemical Engineering, Northeast Petroleum University, Daqing, China \\ ${ }^{2}$ Environmental Inspection Team, Yi'an County, Qiqihar, China \\ ${ }^{3}$ Daqing Oilfield Engineering Co. Ltd., Qaqing, China \\ ${ }^{4}$ Daqing Oilfield Production Technology Institute, Qaqing, China \\ Email: 48184820@qq.com, ghw328@163.com, 14114988@qq.com, zcgh@petrochina.com.cn, \\ zhangdianxu@petrochina.com.cn
}

Received 23 August 2014; revised 22 September 2014; accepted 22 October 2014

Copyright (C) 2014 by authors and Scientific Research Publishing Inc.

This work is licensed under the Creative Commons Attribution International License (CC BY).

http://creativecommons.org/licenses/by/4.0/

(c) (;) Open Access

\begin{abstract}
The consumption of dye-sensitized solar cells (DSSCs) used to produce hydrogen, compared with the traditional water-splitting energy, is much less. First of all it is because of DSSCs' low cost, easy fabrication process, high conversion efficiency and good stability; secondly it also solves the problem of serious corrosion of the electrode, for the entire solar system is in the air. We use three tandem dye-sensitized photovoltaic cells as a source of power; the open circuit voltage of photoelectric unit shows the feasibility of using dye-sensitized photovoltaic cell decomposition of water to produce hydrogen.
\end{abstract}

\section{Keywords}

Dye-Sensitized Solar Cell, Coupling, Hydrogen, System of Water-Splitting for Hydrogen Production

\section{Introduction}

Utilization of solar energy decomposition of water into hydrogen has been a hot topic of research; the reaction mechanism of photocatalytic water splitting can be seen from Figure 1. The traditional DSSCs water-splitting systems were done directly $\left(\mathrm{TiO}_{2}\right.$ as water-splitting photoanode [1] and Pt as counter electrode); the two electrodes were immersed in the electrolyte. After $\mathrm{TiO}_{2}$ electrode is exposed to light, Pt electrode has the hydrogen generation. Because of $\mathrm{TiO}_{2}$ anode energy shortage and the need to add bias to the electrolysis of water, the electrolytic efficiency of this method has not been improved greatly. But the spectral sensitivity of the photoelectric

${ }^{*}$ Corresponding author. 


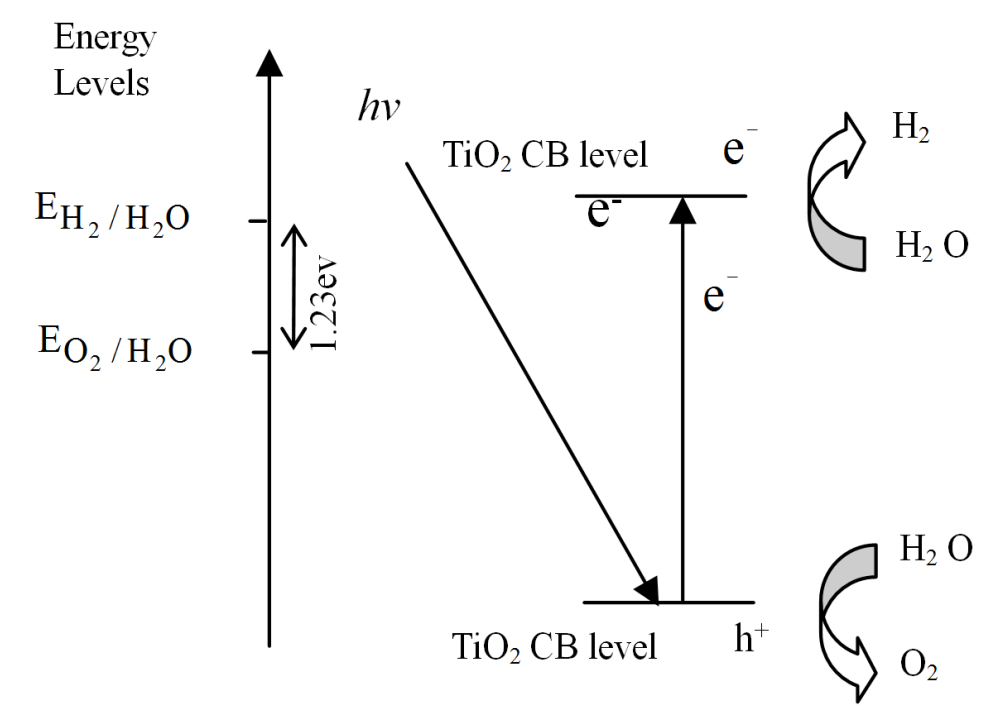

Figure 1. The reaction mechanism of photocatalytic water splitting.

material is not ideal; since the whole decomposition processes were completed in the solution, the corrosion problem of electricity was also more serious. Taking all these factors, we improved the traditional DSSCs watersplitting system, using dye-sensitized photovoltaic cells coupled water-splitting electrode, and two units coupled directly to establish a system of water-splitting for hydrogen production.

\section{Experimental}

\subsection{Production of DSSCs}

\subsubsection{The Film Preparation Method}

The anode of DSSCs films made by sol-gel add powder method. A certain amount of nano- $\mathrm{TiO}_{2} \mathrm{powder}^{\text {is add- }}$ ing in $\mathrm{TiO}_{2}$ sol, and add a certain amount of polyethylene glycol, sufficiently stirred, ultrasonic dispersion to obtain $\mathrm{TiO}_{2}$ slurry. $\mathrm{TiO}_{2}$ film composition prepared using different process methods or parameters, structure, orientation and thickness are the differences.

\subsubsection{Preparation of $\mathrm{TiO}_{2}$ Sol-Gel}

Tetrabutyl titanate hydrolysis reaction in an acidic solution [2]:

$$
\begin{gathered}
\mathrm{Ti}(\mathrm{OR})_{4}+\mathrm{H}_{2} \mathrm{O} \rightarrow \mathrm{Ti}(\mathrm{OR})_{3}(\mathrm{OH})+\mathrm{ROH} \\
\mathrm{Ti}(\mathrm{OR})_{4}+4 \mathrm{H}_{2} \mathrm{O} \rightarrow \mathrm{Ti}(\mathrm{OR})_{4}+4 \mathrm{ROH} \\
\mathrm{Ti}(\mathrm{OR})_{4}+\mathrm{Ti}(\mathrm{OR})_{3}(\mathrm{OH}) \rightarrow \mathrm{Ti}(\mathrm{OR})_{3} \mathrm{O}(\mathrm{RO})_{3} \mathrm{Ti}+\mathrm{ROH} \\
\mathrm{Ti}(\mathrm{OR})_{3}(\mathrm{OH})+\mathrm{Ti}(\mathrm{OR})_{3}(\mathrm{OH}) \rightarrow \mathrm{Ti}(\mathrm{OR})_{3} \mathrm{O}(\mathrm{RO})_{3} \mathrm{Ti}+\mathrm{H}_{2} \mathrm{O}
\end{gathered}
$$

The hydrolyzed reaction mainly (1) and (2) out of the way, the product was incomplete hydrolyzate $\mathrm{Ti}(\mathrm{OR})_{3}(\mathrm{OH})$ and $\mathrm{Ti}(\mathrm{OH})_{4}, \mathrm{Ti}(\mathrm{OH})_{4}$ lose a water molecules generated $\mathrm{TiO}_{2}$ colloidal particles. Polycondensation reaction (3) and (4) happened after the colloid place a period of time, polycondensation product form titanium oxide, colloidal case thickens to form a gel.

Chemically pure tetrabutyl titanate as raw material in this experiment, tusing ethanol as solvent, diethanolamine as complexing agent, nitric acid as catalyst. Experiment steps were as follows:

1) Prepare a mixture A with tetrabutyl titanate, ethanol and diethanolamine, fully stirred to give a homogeneous mixture.

2) Prepare a uniformly mixed mixture A with ethanol, deionized water and nitric acid.

3) Under magnetic stirring, the above mixture B was added into the mixture A dropwise to obtain a uniform, light yellow transparent sol, and the hydrolysis polycondensation reaction at room temperature to obtain sol C. 


\subsubsection{Production of DSSCs}

The $\mathrm{TiO}_{2}$ film was prepared by sol-gel add powder method, drying at room temperature and then placing the crucible in a muffle furnace at $20^{\circ} \mathrm{C} / \mathrm{min}$ at $500^{\circ} \mathrm{C}$ heated to a constant temperature for two hours, then cooled in the furnace. After hydrolysis of the intermediate product suitable high-temperature annealing was completely decomposed, residual organic matter can be completely removed, and finally completely dehydrated, only closely integrated with the substrate of titanium dioxide films.

The counter electrode was prepared by electroplating method on FTO conductive glass with pt. Eosin Y as sensitizer.

\subsection{Experimental Device}

Figure 2 is the experimental device, and is a integrated efficiency self-coupling solar water-splitting system for hydrogen production [3]. Three DSSCs as the photoelectric unit in series, are connected between each cell with palladium sheet. The anode electrode used in the electrolytic unit is the ruthenium oxide coated titanium electrode, and a platinum plate with $1 \mathrm{~mol} / \mathrm{L} \mathrm{KOH}$ electrolytic solution as the cathode, maximum conversion efficiency was achieved by adjusting parameters of the photoelectric unit and the electrolytic unit.

Figure 3 is a schematic diagram of the electrode reaction of water electrolysis process. Composition of elec-

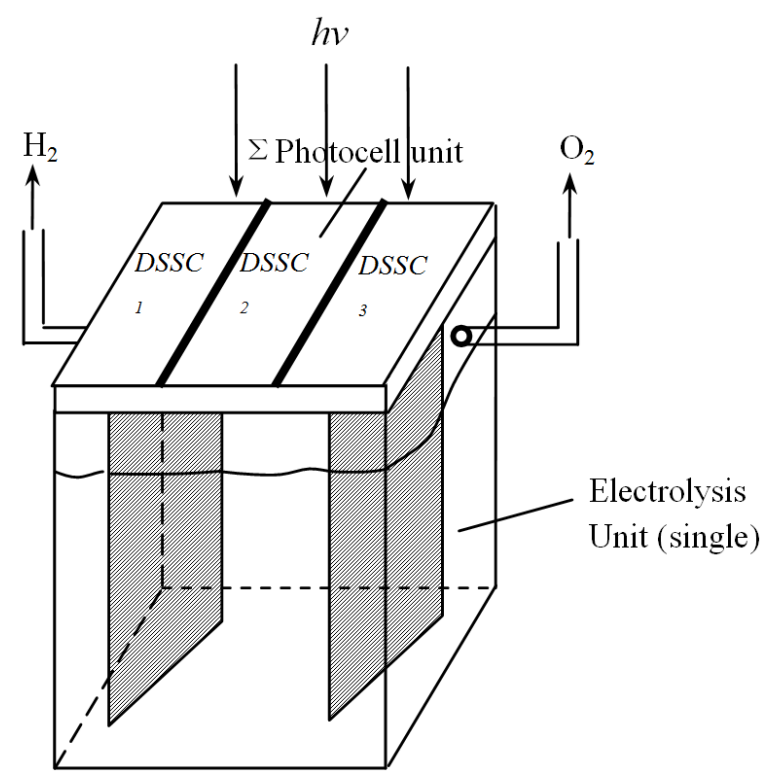

Figure 2. Integrated self-coupling solar water-splitting system for hydrogen production.

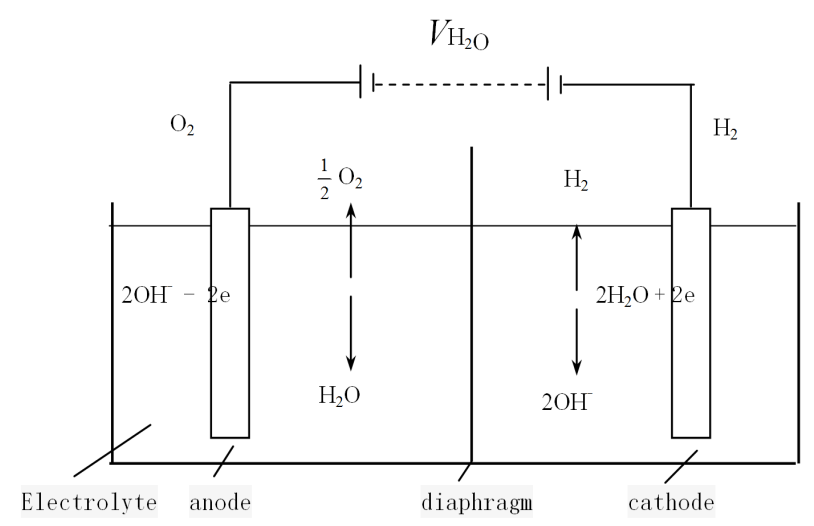

Figure 3. Schematic diagram of the electrode reaction of water electrolysis process. 
trolytic cell is mainly composed of a power supply, electrolyzer, electrolyte, cathode, anode and diaphragm. The diaphragm consists mainly of asbestos, the main role of separation from the gas, and the two electrode is mainly plays the role of electrocatalysis decomposition of water, to produce hydrogen and oxygen. At the cathode, two water molecules is decomposed into two hydrogen ions and two hydroxide ions, hydrogen ions are generated electron hydrogen atom, and further generates a hydrogen molecule, hydroxide ion in the electric field force between the anode and cathode through the porous diaphragm, reach the anode, the anode loses two electrons to form a water molecule and 1/2 oxygen molecule.

\section{Results and Discussion}

Testing the DSSCs with Beijing Changtuo Company CHF-XM-500W xenon lamp as the light source, the incident light intensity was $73.1 \mathrm{~mW} / \mathrm{cm}^{2}$. Figure 4 and Figure 5 is an I-V curve and P-V curves of three dye-sensitized solar cells in series.

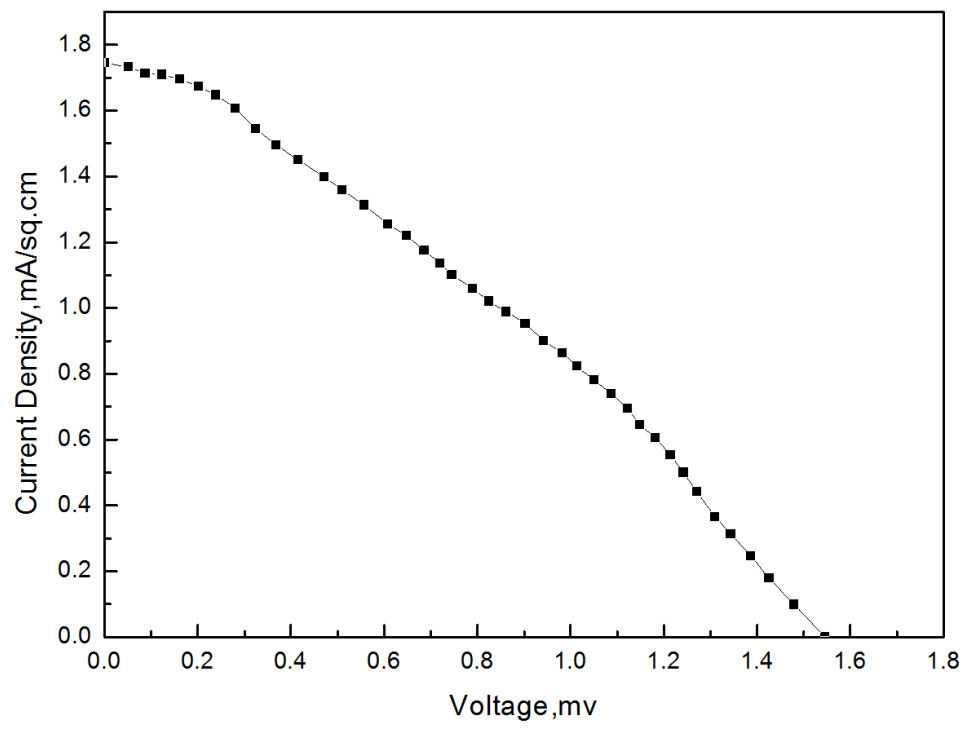

Figure 4. I-V curve of three dye-sensitized solar cells in series.

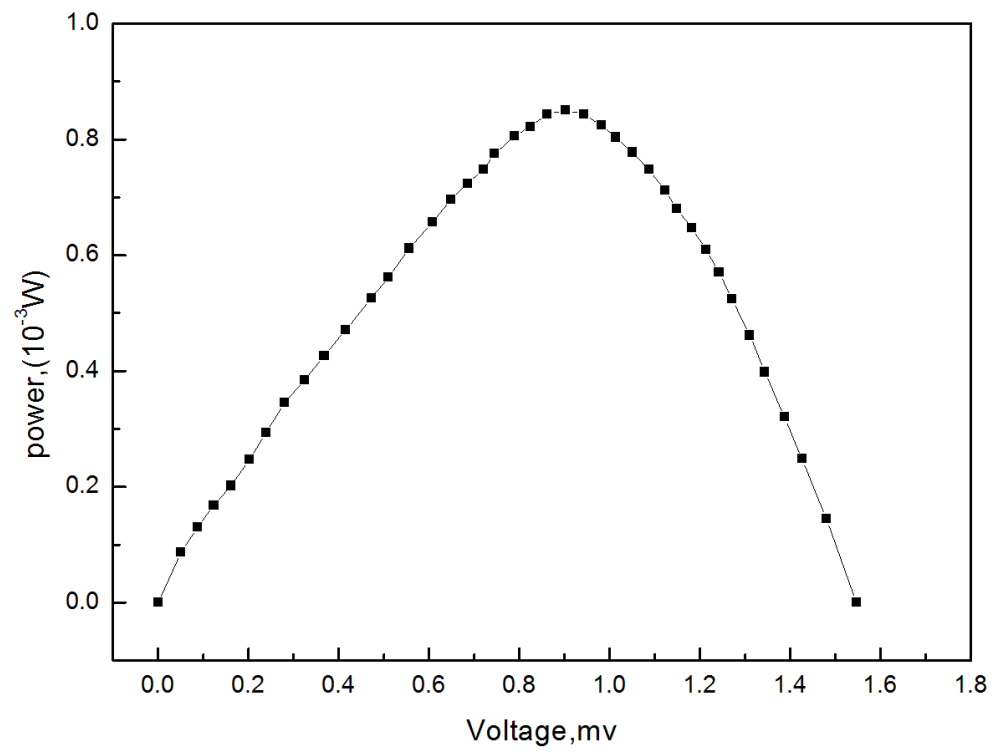

Figure 5. P-V curves of three dye-sensitized solar cells in series. 
We could know that the open-circuit voltage of the photoelectric cell system was $1.547 \mathrm{~V}$ from Figure 4, showed the feasibility of the dye-sensitized solar cell decomposition of water to produce hydrogen, but also we could know that that the maximum power point voltage of the photoelectric cell is $0.902 \mathrm{~V}$ from Figure 5 . The water-splitting system operation in the $1.3-1.4 \mathrm{~V}$ optical voltage, also shows the photoelectric system still need to be further optimized.

\section{Conclusions}

1) The photoelectric unit and electrolysis unit directly from the coupling integrated into an efficient selfcoupled water-splitting for hydrogen subsystem. Modulation of photoelectric cell material, size, photovoltaic cells intrinsic properties, as well as modulation electrolytic cell material, size, electrolytes, etc., can make photoelectric cells and electrolysis unit well matched, including spectral match, potential match, power matching, etc., and can maximize solar energy utilization efficiency, which can build into a highly efficient integrated selfcoupling of solar water-splitting system.

2) Based on the basic principle of the photoelectric unit and theoretical analysis, the model and the theory of the photoelectric cell are similar to those of ordinary solar cells.

3) Three series of dye-sensitized photovoltaic cell system under simulated light irradiation resulted in the open circuit voltage of $1.547 \mathrm{~V}$; this voltage exceeds the voltage of the electrolysis reaction thermodynamic theory, which can promote the photoelectric response, but since the fill factor of the photoelectric unit is low, resulting in the maximum power point voltage of the photoelectric unit in $0.902 \mathrm{~V}$, the decomposition voltage of water is not well matched. There are two ways to optimize in the experiment: one is further optimization of single-cell system, and the other is to make dye-sensitized photovoltaic cell series-parallel combined.

\section{References}

[1] Fujishima, A. and Honda, K. (1972) Electrochemical Photolysis of Water at a Semiconductor Electrode. Nature, 238, 37-38. http://dx.doi.org/10.1038/238037a0

[2] Pandey, R.N., Chandra Babu, K.S. and Srivastava, O.N. (1996) High Conversion Efficiency Photoelectr-Ochemical Solar Cells. Progress in Surface Science, 52, 125-192. http://dx.doi.org/10.1016/0079-6816(96)00009-3

[3] Khaselev, O., Bansal, A. and Turner, J.A. (2001) High-Efficiency Integrated Multijunction Photovoltaic/Electrolysis Systems for Hydrogen Production. International Journal of Hydrogen Energy, 26, 127-132. http://dx.doi.org/10.1016/S0360-3199(00)00039-2 
Scientific Research Publishing (SCIRP) is one of the largest Open Access journal publishers. It is currently publishing more than 200 open access, online, peer-reviewed journals covering a wide range of academic disciplines. SCIRP serves the worldwide academic communities and contributes to the progress and application of science with its publication.

Other selected journals from SCIRP are listed as below. Submit your manuscript to us via either submit@scirp.org or Online Submission Portal.
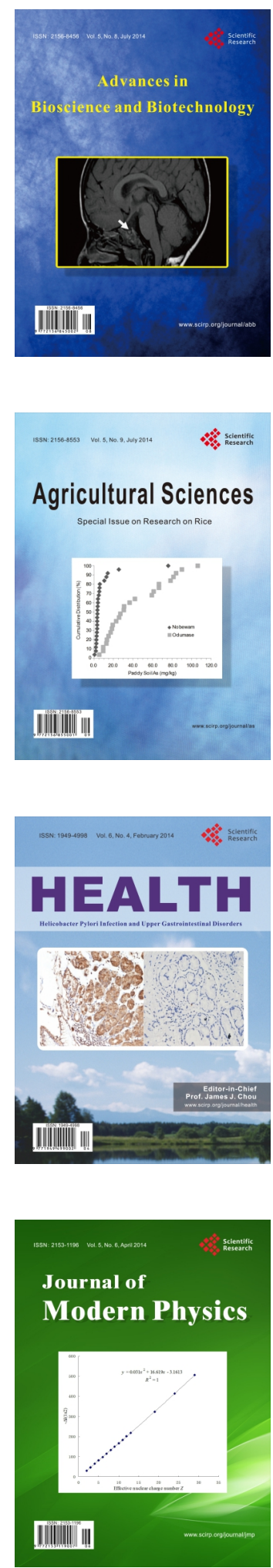
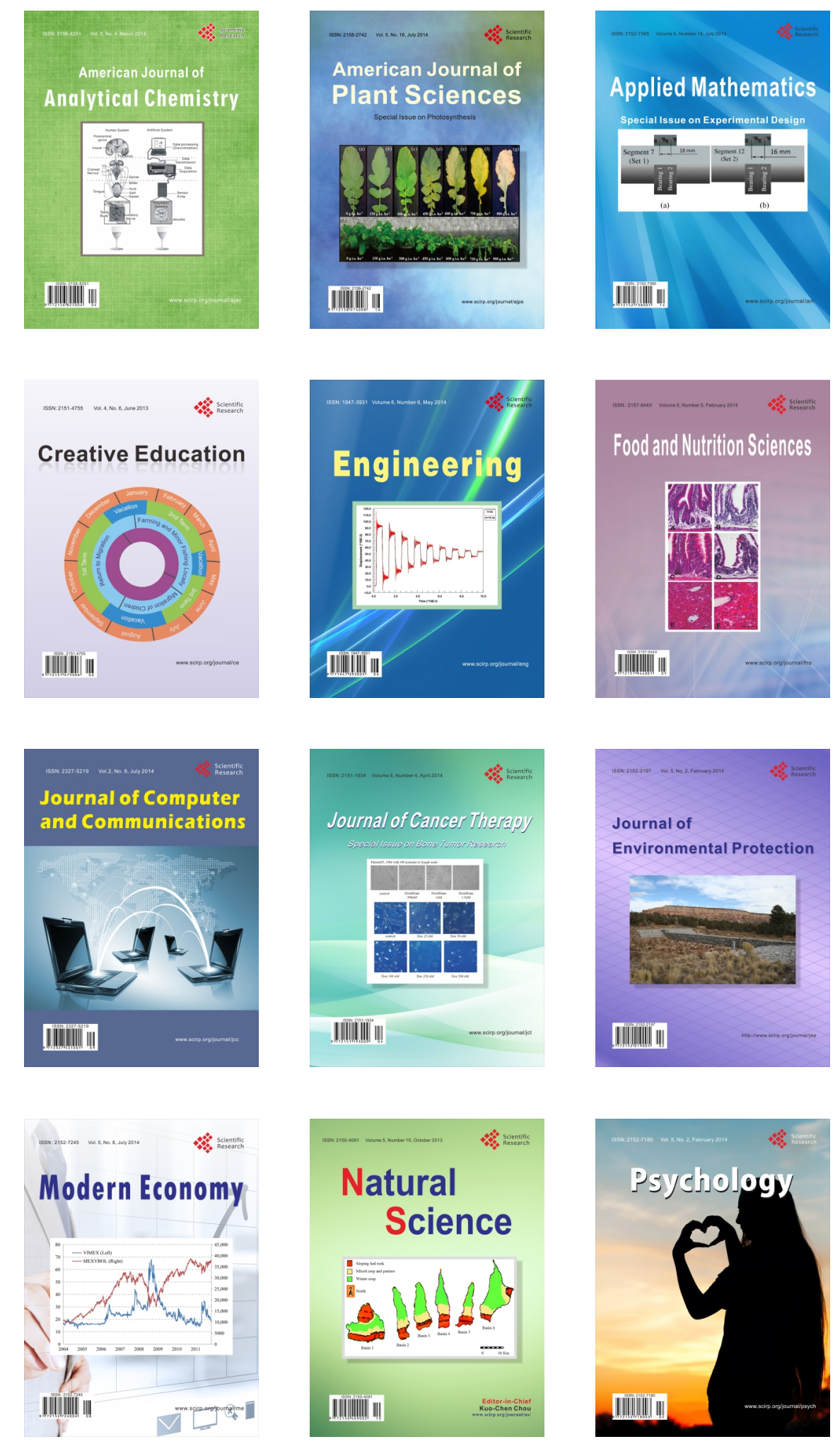